\title{
Patience pays laser inventor in lifetime battle over patents?
}

\section{Washington}

A 28-year legal battle ended last week with Dr Gordon Gould's claim to have invented - or at least improved - the laser finally vindicated. On Wednesday he was presented with a patent for the gas discharge laser that he had applied for in 1959 and has been fighting for ever since. Ironically, Gould is far better off for having been forced to wait: had he received his patent quickly it would have expired long before the laser industry took off - now the patent runs until 2004 and may be worth hundreds of millions of dollars.

Last week's success follows hard on the heels of victory in a legal fight over an-

\section{Pending patent law good news for some}

\section{London}

THE British government has finally published details of long-awaited legislation to get to grips with outdated and confused copyright and patent laws. The Copyright, Designs and Patents Bill is scheduled to be put before the House of Lords this week, and is expected to become law by next summer.

One prominent feature of the bill is that the government has resisted pressure from the music industry by backing down from imposing a 10 per cent levy on blank audio tapes to compensate copyright holders for lost revenue from people recording tapes at home. Plans to impose a levy had been announced in the policy document that preceded the bill (see Nature 327, 549; 1987). Home taping and video taping will remain illegal, despite the government's admission that the law is virtually unenforceable.

The bill brings good news for the pharmaceutical industry by removing the 'licence to right' that allows companies to copy successful drugs during the last four years of their 20-year patent protection. The government says the modification of the law is in recognition of the length of time it takes from patenting a new drug to its appearance in the market place, which is often as long as 12 years, and which gives companies little time to make profits.

The new law will make it easier and less expensive for disputes over patents and designs to be settled by allowing actions to be brought before a lower court than is presently the case, and the problem of getting copyright clearance to record broadcasts for use in school is removed.

Simon Hadlington other key patent - for the optically pumped laser - that is also held by Gould. Although that patent was issued in 1977 it remained under appeal at the US Patent Office for almost ten years. Only two weeks ago was it finally validated when a patent infringement suit was won against Control Laser Corporation in a Florida court. Gould's two patents together could cover as much as 80 per cent of the lasers being produced in the United States - a market worth $\$ 500$ million a year now and doubling in size every four years.

Sharing Dr Gould's obvious happiness were the officers of Patlex Corporation, a company set up specially to help Gould and which has spent millions of dollars backing his claims in the courts. That has been a considerable gamble, for the company's biggest asset is its 64 per cent income interest in Gould's patents. Elsewhere, the company part owns three small Israeli high-technology armament manufacturers and a US laser company.

Despite legal recognition of his claim to have invented the laser, Gould has yet to see his name written on the pages of scientific history. He says he set down the ideas for the laser in two straight days of thinking and writing when he was a graduate student at Columbia University's Radiation Laboratory in 1957. Columbia, he says, was a "terrific place .. . the foremost laboratory in the world in microwave spectroscopy, the field in which the laser had to be born". Gould had already received training in optical spectroscopy at Yale University and that, in combination with the microwave techniques available at Columbia, led him towards the laser. But it was not until two years after he set down his ideas of the laser, in 1959 , that he applied for a patent. In the interim, a patent application for the laser, then known as the "optical maser" had already been filed by another Columbia University researcher, professor Charles Townes.

Townes has always been regarded as the father of the laser. His paper, published in Physical Review in 1958 with A.L. Schawlow, is seen as a milestone in the histroy of the laser. And in 1964 Townes won the Nobel prize, together with two Soviet scientists, for the fundamental work in quantum studies that made the maser and laser possible.

Patlex officials, with great pride in their protégé, believe that Gould should also have been a candidate for the Nobel Prize. But Gould himself is more sanguine. $\mathrm{He}$ says only that it was all his fault that he was not recognized for he was "too ignorant" to know how to apply for a patent when he first had the idea for the laser. He sees his own and Townes's work as complimentary. Townes's and Schawlow's classic paper showed that the Fabry-Perot interferometer provided the appropriate cavity for laser oscillation. Gould built on Townes's studies but concentrated on the appropriate excitation mechanisms.

There was no close link, Gould says, between Townes and himself because "I was a student and he was a professor". Townes remembers Gould well as a student, but regards his contribution as more of an improvement than the addition of something new. Gould, in any case, appears little concerned with the events of

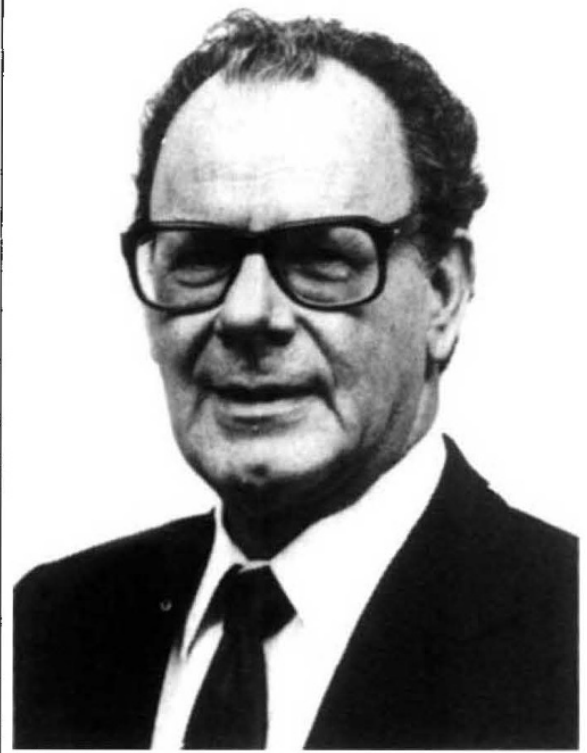

Gordon Gould - in the money?

the past. He is much more worried about the extraordinary difficulties of patent licensing in the United States and the effect this may have on individual inventors and the ability of the United States to compete with other countries. Nor are an inventor's worries over when a patent has been granted. As Gould puts it "all a patent gives you is the license to sue infringers". Both legal action and examination of a patent can be ruinously expensive and a patent can be overturned in court after it is issued.

Gould believes his patent will survive. In the decades it has taken to obtain his patents every possible legal objection has already been raised, he believes. In the United States, at least, he thinks that companies are now more likely to enter licensing agreements than to go to the expense of challenging the patent in court. But an unpleasant surprise may yet come along. The patent will not apply aboard for, with the principal exception of Canada, patents run from the date of application rather than the date of issue and, in Gould's case, would long since have expired. But as the United States is by the far the largest producer of lasers, Gould may be able to sit back and see the millions flow in.

Alun Anderson 